\title{
Screening and Sequencing of the Affecting Factors of Residential Owner Satisfaction Based on Key Events
}

\author{
Miao Yue ${ }^{1, a}$, Li yinghui ${ }^{2, b}$ \\ ${ }^{1}$ Department of Tourism Management, Changsha University, Changsha, , 410003, China \\ ${ }^{2}$ Department of Tourism Management, Changsha University, Changsha, , 410003, China \\ aemail: 443828163@qq.com, bemail: liyh899@126.com
}

Keywords: Property management; Customer satisfaction; Influencing factor; Key event; Screening; Sequencing.

\begin{abstract}
Using the key incident method, we found three main major factors which affecting owners' satisfaction: service quality, safety management, cost and fund management. And by theoretical analysis and empirical investigation, we constructed an owners satisfaction index system, screened and sequenced these affecting factors. The research can provide theoretical basis and empirical evidences to enterprises for their customer satisfaction measurements, help property companies to understand the working key, and find the practical and feasible countermeasures which can improve the satisfaction of owners.
\end{abstract}

\section{Introduction}

The Chinese property service enterprise is bearing the costs continually rising and the industry is facing increasingly fierce competition pressure. In order to increase the market share and keep competitive in the market, the need of raising customer satisfaction to reduce disputes and maintain customer loyalty is urgent. In practice, due to the limited level of management, the vast majority of property service enterprise use direct inquiry way to investigate and track the owner's satisfaction degree. But, prior research suggested that influenced by the current situation and the psychological of multiple factors, the proportion which expressed completely satisfied or very satisfied was higher than the actual. And while those respondents expressed discontent, often due to personal emotional catharsis, information distortion or leakage was appeared, unable to truly reflected the views of customers. So, this approach was not conductive to reflect the impact of customer satisfaction factors and unable to provide management decision-making for enterprises. In view of this, we tried to use the key incident method, through online forums to collect the factors which influenced customer satisfaction, formed customer satisfaction factors hierarchy index combining with the expert opinion. However through the relevant questionnaires, we analyzed and verificated the relevant influence coefficient.

\section{Literature Review}

A. the Concept of Consumer Satisfaction

Scholars has put forward a variety of understanding and awareness on customer satisfaction from different angles: Hunt suggested that customer satisfaction was coming from experience and evaluation[1]. Oliver and Linda (1981) believed that customer satisfaction was a psychological state when their consumer expectations were met [2]. Churchill and Surprenant (1982) defined the customer satisfaction as the result of purchasing and using products, which was derived from the expected returns and costs were compared[3]. Oliver (1993) thought that customer satisfaction was the customers' feedback, which expressed the evaluation of the product or service's performance, given or was giving the level of happiness in relation to consumer satisfaction, including less than or more than satisfaction level[4]. To sum up, customer satisfaction is a psychological state, it is related with the customer experience, and it is a state of feeling when the customers compare their perceived effect with their expectations. 


\section{B. Property Management Consumer Satisfaction and its Influenting Factors}

Researches showed that the three factors which impact the customer satisfaction were: customer expectation, perceived quality and value perception. Customer expectation is customer expectation to enterprise products and services. Especially when they get the information through the media (such as advertisement, salesman and other customers reputation etc.), their expectations will be greatly affected. Perceived quality is the evaluation coming from the customer's recent consumption experience on product and service. It is effected by customer expectation. Perceived value is customer's feeling of the product and service quality compared with their paying. Joining these factors can increase the customer satisfaction index in different industries and enterprises of comparability.

Specific to the property management industry, domestic related literature is not much. Only Feng Mengjie[5] (2005) in the study on the influence factors of customer loyalty in service industry, she picked property management industry as samples, and she put forward a series of service quality measurement tools which were suitable for China's property management background. But her main purpose was to explore the mechanism of customer loyalty in service industry, while less attention to the customer satisfaction factors. Jiang Qiuxia (2007) [6] thought that the assurance factors of service quality (such as friendly attitude and competence of the staff, that will enhance customer confidence and sense of security on enterprise's service quality), transference factors(enterprise care for customers sincerely, understand the needs of customers) have a more direct influence on customer satisfaction. The above researches provided a good idea for our paper, but they just applied the foreign service quality, customer satisfaction scale to the study on domestic property management industry directly, not carried out an in-depth factor analysis targeting at Chinese property management practice issues. Therefore, this paper concentrated on the study of property management customer satisfaction and its influencing factors.

\section{Screening of the Affecting Factors of Residential Owner Satisfaction Based on Key Event}

This study used the key events method and comparative research method. Based on the collection of key events which reflected property management complaints, identified the various key behaviors which led owners to spread the negative emotions, we collected 243 key events, referenced Kay Winnie (Keaveney, S.M ) studies of category which she had used in customer switching services, classified these 243 key events, and increased and decreased according to the need of the category. The collected cases mainly came from Hunan and residential real estate information network ( http://www.hunfdc.com ) , Hunan property network (http://www.0731wy.com/) , Changsha joint real estate network (http://www.csfdc.gov.cn/) and some residential area property owners forums. With the collection and analysis of the key events, we found that main reasons which led to the owners discontented were as follows: the quality of service, security management, cost and capital management. Then we further refined them to 14 second-level indexes, and through the relevant expert advice, removed two contents: fire safety management and fees range. The results were as follows:

TABLE I SCREENING TABLE OF INFLUENCing FACTORS OF PROPERTY MANAGEMENT

\begin{tabular}{|l|c|c|}
\hline C1 .Service Quality & C2 Saf ety Management & C3 Cost and Fund Management \\
\hline C11: Service Attitude & C21: Household Safety Management & C31:The Rationality of Charge \\
\hline $\begin{array}{c}\text { C12: The Timeliness } \\
\text { of Services }\end{array}$ & C22:Vehicle Safety Management & C32: The Charge Publicity. \\
\hline $\begin{array}{l}\text { C13: Service Integrity } \\
\text { C14:The Prospective Service }\end{array}$ & $\begin{array}{c}\text { C23: Education of } \\
\text { Safety Management }\end{array}$ & $\begin{array}{c}\text { C33: The Transparency } \\
\text { of Cost }\end{array}$ \\
\hline & $\begin{array}{c}\text { C25:Fire Safety } \text { The Use of Special Funds } \\
\text { Management (Delete) }\end{array}$ & C35: Fees Range (Delete) \\
\hline
\end{tabular}




\section{A Sevice Quality}

Property service quality was the important factor to influence customer satisfaction. It is important to identify those critical behaviors which related with core service error and technical performance, including those which can not meet the the owners' demands, or promises have not been achieved. Specific content were as follows: (1) Service attitude, including service initiative, enthusiastic service level, and etc. (2) The timeliness of services, including service information timeliness and service timeliness. (3) Service integrity, including the completion of the basic property service quality, and the completeness of service items and service spirit. (4) The prospective service, including the existing property value-added services and the providing degree of property leasing advisory.

B Safty Management

Property management complaints focused on the safety management, mainly involved the following four aspects:(1) Household safety management, including personal safety management and the safety of property management. (2) Vehicle safety management, including park order, order of vehicle maintenance and vehicle safety maintenance. (3) Education of safety management, especially for the safety consciousness cultivation and security knowledge propaganda. Incident management, including the preventive measures and corresponding emergency plan.

C. Cost and Fund Management

Property management fees and special fund management are controversial :issues in property management. The owners complain concentrated on the following three aspects: (1) The rationality of charge, including the high fees, charges of unfair, deceptive price and price hikes. (2) The charge publicity, including fees and charges no publicity, pool charges induced by doubts, and etc. (3) The transparency of cost. (4) The use of special funds.

\section{Sequencing and Application of the Affecting Factors of Residential Owner Satisfation}

Based on the above analysis and our survey, we established the CSI index system and designed the questionnaire. The index system was combined of 12 indexes, and we sent out 200 questionnaires randomly to the owners of residential quarters in six cities of Hunan province(Changsha, Zhuzhou, Xiangtan, Changde, Hengyang, Chenzhou), 174 valid questionnaires recovered, effective rate of recovery is $87 \%$. Owners surveyed scored each index according to its important degree, 1 shows unimportant, 5 shows very important, then we aggregated scores with the city as the unit, sequencing each single index score, and using Kendall coefficient of concordance to test whether the index system was reasonable, and finally, we got the weight of each index. The results were in table II :

TABLE II PROPERTY MANAGEMENT INFLUENCING FACTORS EMPIRICAL SATISTICAL DATA TABLE

\begin{tabular}{|c|c|c|c|c|c|c|c|c|c|c|c|c|}
\hline \multirow{4}{*}{$\begin{array}{c}\text { Index } \\
\text { Rij }\end{array}$} & \multicolumn{5}{|c|}{ C1 } & \multicolumn{5}{c|}{ C2 } & \multicolumn{5}{c|}{ C3 } \\
\cline { 2 - 15 } & C11 & C12 & C13 & C14 & C21 & C22 & C23 & C24 & C31 & C32 & C33 & C34 \\
\hline Changsha & 1 & 5 & 4 & 8 & 2 & 6 & 12 & 10 & 3 & 9 & 7 & 11 \\
\hline Zhuzhou & 2 & 4 & 5 & 9 & 1 & 7 & 12 & 8 & 3 & 11 & 6 & 10 \\
\hline Xiangtan & 3 & 7 & 6 & 11 & 1 & 8 & 9 & 5 & 2 & 4 & 12 & 10 \\
\hline Changde & 1 & 6 & 5 & 10 & 3 & 4 & 11 & 9 & 2 & 7 & 8 & 12 \\
\hline Hengyang & 2 & 5 & 8 & 12 & 1 & 3 & 10 & 6 & 4 & 7 & 9 & 11 \\
\hline Chenzhou & 2 & 8 & 5 & 12 & 1 & 7 & 11 & 4 & 3 & 6 & 9 & 10 \\
\hline Ri & 11 & 35 & 33 & 62 & 9 & 35 & 65 & 42 & 17 & 44 & 51 & 64 \\
\hline
\end{tabular}




$$
\mathrm{S}=\sum_{i=1}^{12}\left(R i-\sum_{i=1}^{12} R i / 12\right)^{2}=4244
$$

Below we further calculate the weight of CIS index:

$\mathrm{Ri}=\sum_{\mathrm{j}=1}^{\mathrm{b}} \mathrm{R}_{\mathrm{ij}}$

means the sum of rank $i, b$ is the the total number of investigated cities. The more consistent with the questionnaire results, the larger difference among R1、R2、...R12.

So we can use

$$
\sum_{i=1}^{12}\left(R i-\sum_{i=1}^{12} R i / 12\right)^{2}
$$

to test the consistency of surveyed owners opinions, and with statistic which is less than 1 to make a significance test

Maximum value: $\mathrm{M}=\mathrm{b} 2 \mathrm{n}(\mathrm{n} 2-1) / 12=5148$

We can deduce: $\mathrm{W}=\mathrm{S} / \mathrm{M}=4244 / 5148=0.824$

On consistency $\chi^{2}$ test:

$$
\chi^{2}=\mathrm{b}(\mathrm{n}-1) \mathrm{W}=6 * 11 * 0.824=54.384>\chi^{2} 0.01 \text { (11) }=15.086
$$

The results showed that for the important degree of 12 factors which influence their satisfaction, six cities respondents had a relatively high degree of consistence. This indicted that

\begin{tabular}{|c|c|c|c|c|c|c|c|c|c|c|c|c|}
\hline \multirow{2}{*}{ Weight Index } & \multicolumn{4}{|c|}{ C1 } & \multicolumn{4}{|c|}{$\mathrm{C} 2$} & \multicolumn{4}{|c|}{ C3 } \\
\hline & C11 & C12 & C13 & C14 & C21 & C22 & C23 & C24 & C31 & C32 & C33 & C34 \\
\hline$R i=\mathrm{Ri} / 12$ & 0.92 & 2.92 & 2.75 & 5.17 & 0.75 & 2.92 & 5.42 & 3.5 & 1.42 & 3.67 & 4.25 & 5.33 \\
\hline $\mathrm{Qij}=\mathrm{n}+1-\overline{R i}$ & 12.08 & 10.08 & 10.25 & 7.83 & 12.25 & 10.08 & 7.58 & 9.5 & 1.58 & 9.33 & 8.75 & 7.67 \\
\hline Qi & \multicolumn{4}{|c|}{40.24} & \multicolumn{4}{|c|}{39.41} & \multicolumn{4}{|c|}{37.33} \\
\hline $\begin{array}{l}\text { Level indicator } \\
\text { for overall } \\
\text { index weight } \\
\mathrm{W} 2=\mathrm{Q} / / \mathrm{Qi}\end{array}$ & \multicolumn{4}{|c|}{0.344} & \multicolumn{4}{|c|}{0.337} & \multicolumn{4}{|c|}{0.319} \\
\hline $\begin{array}{c}\text { Two grade index } \\
\text { for overall } \\
\text { index weight } \\
\text { W3= Qij/ } \sum \mathrm{Qi} \\
\end{array}$ & 10.32 & 8.62 & 8.76 & 6.69 & 10.47 & 8.62 & 6.48 & 8.12 & 9.9 & 7.98 & 7.48 & 6.56 \\
\hline $\begin{array}{l}\text { pverall ranking } \\
\text { influencing factors }\end{array}$ & 2 & 5 & 4 & 10 & 1 & 5 & 12 & 7 & 3 & 8 & 9 & 11 \\
\hline
\end{tabular}
this customer satisfaction index system had high reliability.

TABLEIII PROPERTY MANAGEMENT INFLUENCING FACTORS WEIGHT ANALYSIS TABLE

\section{Conclusion Discussion and Limitations}

From the table we can see, the weight of these three first-grade indexes were not much different, that means if we want to improve the owners satisfaction, improving the quality of service, strengthen safety management and reasonable and effective using of funds are the same important. In two-grade indexes, the top three were: household safety management, service attitude and the rationality of charge. We can further draw the following conclusions: (1) In the environment that the current city social security system is not sound, owners pay more attention to their personal safety. (2) Improving service attitude is the core task of the property management, and it is very 
important to keep good communication environment between owners and property companies. (3) Service charge should cause the property company especially the relevant competent administrative department concern. Our national economy is less developed, owners are sensitive to price, so, government should take further consideration in making a reasonable price which owners and property companies are willing to accept. In addition, for some two-level indexes which sorting is relatively backward, such as the prospective service, also should cause enough attention. With the continuous improvement of people's living standard, these kinds of demands will be more and more, property company should be fully consider these demands.

The customer satisfaction of residential owner is a research topic which has a great practical significance, determinating its related factors can provide theoretical basis and empirical evidences to enterprises for their customer satisfaction measurements, help the property companies to understand the working key, and find the practical and feasible countermeasures which can improve the satisfaction of owners. This paper was based on the key events and expert opinions ,but the collected key events were mostly concentrated in the Hunan area, questionnaire sample number was relatively limited, more extensive, in-depth theoretical analysis and empirical investigation should to be done. How to define satisfaction and influencing factors of owners who come from different regions and different types of residential property is worthy of further study.

Acknowledgment

This paper supported by the Social Science Fund(10BJY043), Hunan Educational Bureau (10C0431, XJK011CGD013 ), and Social Science Foundation of Hunan Province, China (11JD03).

\section{References}

[1] Huefner. JC, Hunt, HIK, "Consumer retaliation as a response to dissatisfaction" , Journal of Consumer Satisfaction, Dissatisfaction and Complaining Behavior, 2000, vol.13, pp.13: 61-82.

[2] Oliver, Richard L., "Measurement and Evaluation of Satisfaction Processes in Retailing Setting”, Journal of Retailing, 1981, vol..3, pp.25-48

[3] Churchill, Gilber A., Jr \&Carol Superenant, "An investigation into the determinants of consumer satisfaction", Journal of Marketing Research., 1982, vol.11, pp.491-504

[4] Oliver, Richard L.A, "Conceptual model of service quality and service satisfaction: compatible goal, different concepts. Advances in Service”, Journal of Marketing and Management, 1993 , vol.5, pp. 65-86

[5] Feng, M. J, "The influencing factors of customer loyalty in service industry and its function mechanism - an empirical study on Hangzhou property services" [D], Zhejiang University, 2005

[6] Jiang, M. J, “ the relationship of property management industry's service quality , customer satisfaction and customer loyalty: based on a case study of Hangzhou city" [D], Zhejiang University, 2007

[7] Hou, L.M, "the exploratory study on behavior of customer switching supplier--based on the investigation of Shanghai manufacturers", Journal of Business Economics Review, 2006,vol.11, pp.65-69

[8] Li, J. H, "the research on China financial services customer dissatisfaction factors and reaction behavior", Journal of Industrial Technology Economy, 2008, vol. 27, pp.152-155 